Abstracta Iranica Abstracta Iranica

Revue bibliographique pour le domaine irano-aryen

Volume 31 | 2011

Comptes rendus des publications de 2008

\title{
Qaraqash mädäniyät täzkirisi. Urumchi, Shinjang khälq näshriyati, 2005, 588 p. [Mémoire sur la culture de Qaraqash]
}

Alexandre Papas

\section{(2) OpenEdition}

1 Journals

Édition électronique

URL : http://journals.openedition.org/abstractairanica/39582

DOI : 10.4000/abstractairanica.39582

ISSN : 1961-960X

Éditeur :

CNRS (UMR 7528 Mondes iraniens et indiens), Éditions de l'IFRI

Édition imprimée

Date de publication : 15 mai 2011

ISSN : 0240-8910

Référence électronique

Alexandre Papas, « Qaraqash mädäniyät täzkirisi. Urumchi, Shinjang khälq näshriyati, 2005, 588 p.

[Mémoire sur la culture de Qaraqash] », Abstracta Iranica [En ligne], Volume 31 | 2011, document 168,

mis en ligne le 03 juillet 2013, consulté le 26 septembre 2020. URL : http://journals.openedition.org/ abstractairanica/39582 ; DOI : https://doi.org/10.4000/abstractairanica.39582

Ce document a été généré automatiquement le 26 septembre 2020

Tous droits réservés 


\title{
Qaraqash mädäniyät täzkirisi. Urumchi, Shinjang khälq näshriyati, 2005, 588 p. [Mémoire sur la culture de Qaraqash]
}

\author{
Alexandre Papas
}

eds.

J. Rähimi

M. Sidiq

E. A. Sartekin

M. Mirzäkhmät

A. Qadiri

Gh. Osman

J. Ömär

M. Nuri

E. A. Sartekin

Si l'oasis de Qaraqash (à l'ouest de Khotan, dans le Xinjiang méridional) semble aujourd'hui un peu endormie, elle n'en recèle pas moins une histoire culturelle toujours vivante. C'est à cette histoire que le présent volume collectif souhaite rendre justice. À l'exception de la contribution de J. Rähimi sur les Khwāja Egizeriq (p. 117-132), le lecteur trouvera peu de références au soufisme alors même que la mystique habite véritablement l'islam turkestanais, notamment Qaraqash, depuis le $\mathrm{XV}^{\mathrm{e}}$ siècle. La littérature est à l'honneur puisqu'elle fait l'objet de six articles denses (signés M. Sidiq, E. A. Sartekin, M. Mirzäkhmät, A. Qadiri, Gh. Osman) qui dressent un panorama remontant jusqu'au XVII ${ }^{e}$ siècle. De nombreux passages sont cités. On pourra compléter ce tableau littéraire en consultant les pages consacrées aux arts (p.311-350). Les historiens n'échapperont pas aux articles dédiés à ce que l'historiographie chinoise appelle la libération du Xinjiang, avec ses héros et ses hauts faits; ils profiteront néanmoins de la brève étude de J. Ömär (p. 34-40) portant sur la question scolaire avant1949 et de celle toute aussi laconique mais complémentaire de M. Nuri (p. 60-65) 
sur les madrasas réformistes. Notons enfin, pour les contemporanéistes, l'article d'E. A. Sartekin (p. 455-489) qui dresse un who's who des savants et intellectuels de la ville.

\section{AUTEURS}

\section{ALEXANDRE PAPAS}

CNRS - Paris 